\title{
Overeating as a cause of limb amputations in the Christian Patristic Tradition
}

\author{
Elias E. Mazokopakis ${ }^{1,2}$
}

Received: 18 February 2020 / Accepted: 25 March 2020 / Published online: 1 April 2020

(c) Springer Nature Switzerland AG 2020

Keywords Amputation · Christian Patristic Tradition · Overeating · Passion

Dear Editor,

It is widely known that limb amputation represents one of the oldest and most serious surgical operations [1]. There have been various reasons cited for the execution of limb amputation over the centuries (such as traumatic injuries, infections, gangrene, punishment for people who committed crimes, vascular disorders, diabetes mellitus, and malignancies). However, an association between limb amputation and compulsive overeating behavior is described, to my knowledge, for the first time in the Christian Patristic Tradition. To be more specific, in his ascetical treatise for monasticism, Ladder of Divine Ascent (Greek: Kגí $\mu \alpha \xi$; Latin: Scala Paradisi), Saint John Climacus, also known as John Sinaites (c. 579-649 AD), clearly outlines the psychosomatic passion ("addiction") of binge eating (Greek: $\left.\gamma \alpha \sigma \tau \rho \mu \alpha \rho \gamma \gamma^{\prime} \alpha\right)$ as a "hypocrisy of the stomach, for when it is saturated it complains of scarcity, and when it is loaded and bursting it cries out that it is hungry" [2]. In the same text, the author highlights that "some who were servants of their stomach have cut their members right off, and died a double death" [2]. It is quite evident that by "cut their member right off," Saint John Climacus must be referring to limb amputations performed on overeaters who were also, most likely, obese diabetic patients with peripheral neuropathy

This letter is part of topical collection on Food and addiction.

Elias E. Mazokopakis

emazokopakis@yahoo.gr

1 Department of Internal Medicine, Naval Hospital of Crete, Souda, Chania, 73200 Crete, Greece

2 Department of Theology, National and Kapodistrian University of Athens, Athens, Greece and micro-macroangiopathy. Furthermore, the double death represents the death of the person's soul and body.

Funding None declared.

\section{Compliance with ethical standards}

Conflict of interest The author declares that he has no conflict of interest.

Ethical approval This article does not contain any studies with human participants or animals performed by any of the authors.

Informed consent For this type of study, formal consent is not required.

\section{References}

1. Mavroforou A, Koutsias S, Fafoulakis F, Balogiannis I, Stamatiou G, Giannoukas AD (2007) The evolution of lower limb amputation through the ages. Historical note. Int Angiol 26:385-389

2. SJ Climacus. Ladder of Divine Ascent (Greek: K $\lambda \underline{\imath} \mu \alpha \xi$; Latin: Scala Paradisi), Speech 14th, Patrologia Graeca (PG) 88:864-872

Publisher's Note Springer Nature remains neutral with regard to jurisdictional claims in published maps and institutional affiliations. 